\title{
Improving Students' Reading Skill Through Think-Pair-Share (TPS) Technique
}

\author{
1Muhammad Hudri, ${ }^{2} \mathrm{H}$. Irwandi \\ 1,2Universitas Muhammadiyah Mataram, Mataram, Indonesia \\ 1 mchudory@gmail.com, 2irwandi athaya@ymail.com
}

\begin{tabular}{|c|c|}
\hline Article Info & Abstract \\
\hline $\begin{array}{l}\text { Article History } \\
\text { Received: July 12, } 2018 \\
\text { Accepted: September 30, } \\
2018\end{array}$ & \multirow{2}{*}{$\begin{array}{l}\text { This study aims to investigate how the Think-Pair-Share (TPS) technique can } \\
\text { improve the students' reading skill at English Language Department, } \\
\text { Muhammadiyah University of Mataram. The problem found in the fourth } \\
\text { semester students is that they have low ability in comprehending the text. } \\
\text { The TPS technique is offered by the researcher to solve the problem. Later on, } \\
\text { the design of this research was classroom action research adopted from } \\
\text { Kemmis \& McTaggart which goes through a cycle that consists of four stages } \\
\text { namely planning, acting, observing, and reflecting. At the cycle } 1 \text { the students } \\
\text { failed to meet the criteria of success because only } 14 \text { (fourteen) out of } 30 \\
\text { (thirty) or } 47 \% \text { students who got the minimum passing grade } 75 \text { (seventy } \\
\text { five) and the average score was } 67 \text {. It meant that the study must be } \\
\text { continued to the next cycle. At last, in the cycle } 2 \text { met the criteria of success in } \\
\text { which } 67 \% \text { students or } 20 \text { (twenty) out of } 30 \text { (thirty) students met the } \\
\text { minimum passing grade } 75 \text { and the average score was } 72 \text {. Besides gaining } \\
\text { improvement in the reading score, the students also seemed enthusiastic in } \\
\text { thinking, pairing and sharing their ideas. They stated that this technique is } \\
\text { able to encourage and motivate them in thinking, exploring and sharing } \\
\text { their opinion and ideas. This technique is also good to enhance the } \\
\text { cooperation with other people. Finally, TPS technique is also able to increase } \\
\text { the students'confidence to share their ideas in front of many people. }\end{array}$} \\
\hline $\begin{array}{l}\text { Keywords } \\
\text { Think-Pair-Sharer (TPS); } \\
\text { learning strategy; Reading } \\
\text { Comprehension }\end{array}$ & \\
\hline $\begin{array}{l}\text { Support by: } \\
\text { do) Crossref }\end{array}$ & \\
\hline
\end{tabular}

\section{INTRODUCTION}

Reading is worth-noted for English learners. It provides good model for English writing, provides opportunities to study vocabulary, grammar, and punctuation, and demonstrate the way to construct sentences, paragraphs, and whole text. This skill is also fruitful not only for careers, study and pleasure but also for language acquisition (Harmer, 2007). Reading becomes important because it will bring some advantages. By reading, the students will gain a lot of information from various sources that can add their insights to the world and its development. They also get more additional knowledge which has not gained from lessons at school from the teacher's explanations.

In fact, a research on reading skill in Indonesia has revealed that students' skills particularly in reading comprehension are still far from satisfactory. Sukyadi and Hasanah (2010) state that around $37.6 \%$ of 15 year old students are merely able to read the text without understanding the meaning carried by the text. Only 24.8 of them are able to correlate the text with their prior knowledge. It means that many students still have insufficient ability to comprehend the text.

In line with the previous study, the researchers found their students at the university level have lack of interest and low reading proficiency. Those findings were obtained after doing a preliminary study, the initial action for an action research, by 
administrating a reading test and observing the teaching and learning process at the third semester students of Muhammadiyah University of Mataram. The reading test was multiple choice tests. The average of their reading score is 54 and it is below the standard minimum passing level in the university. In the classroom observation, the students were not enthusiastic and interested in learning reading. They look sleepy and bored during the lesson. They also tended to be passive during teaching and learning process. When the lecturer asks them to read, and then look for the main idea, they do not do it, they wait for another friend and cheat it. It happened because they are lack in vocabulary, have not read, less motivate by themselves. So they get bad score in exam than others. Another problem that coming up is student is bored when they get reading lesson from their teacher. It happened because the teacher use conventional method like student asked to read some text then try to answer the question, or find the main idea.

The demand of providing better learning for English teachers should decide an appropriate technique that helps the students have better understanding when they read. Cooperative learning is considered promising by many experts to develop the students' reading skills in the classroom. Cooperative learning is an effective way to improve language skill for students (Kagan \& Kagan, 2009). One of the most effective techniques in cooperative learning is Think-Pair-Share (TPS)

Think-Pair-Share is a collaborative learning strategy in which students work together to solve a problem or answer a question about an assigned reading. This technique requires students to think individually about a topic or answer a question and shares ideas with classmates. Discussing an answer with a partner serves to maximize participation, focus attention and engage students in comprehending the reading material. Working together with their peers can make the students more active and comfortable in the learning process. They think in pairs to understand the message in the text, and then share it to others. It could challenge amongst the pairs to do the best. Thus, the learning process becomes student-oriented. It also provides them sufficient time to express their ideas to their peers in the class.

Some studies that were conducted showed the effectiveness of TPS in teaching reading (Rahvard, 2010; Wichadee, 2004; Nejad \& Keshavarzi, 2015; Naluraya, et al, 2014; Nikmatul Jannah, 2013; Sugiarto \& Sumarsono, 2014; Shih \& Reynolds, 2015). It did not only improve learner reading skill, but also engaged them more in reading class (Sampsel, 2013). Therefore, TPS is effective as a solution for low reading ability and less classroom participation. It can improve their reading proficiency and foster their motivation toward reading English texts.

Sugiarto (2014:212) noted some important benefits of using TPS in his study. First, it improves communicative skill. Sharing ideas to classmates help students learning how exchanges ideas or opinion appropriately. Second, it makes them more actively participate in the classroom. They become more confident by working with a partner, and then sharing their work to other classmates. Third, it improves solidarity and tolerance amongst students. They learn how to respect each other if they have different opinions. Fourth, it helps teacher teaching big numbers of students. Teacher can facilitate and monitor the discussion and give assistance whenever they need.

As the conclusion, TPS is one of effective solution for the teaching and learning reading at the third semester students. It is going to help them improving their reading skill and engage them to be more active in the classroom. This study will provide how the teaching strategy will be implemented in teaching reading. 


\section{METHOD}

This research applied Classroom Action (CAR), Kemmis and McTaggart (1988). It is called CAR because the research focused on a particular problem and a particular group of students in a certain classroom. This research focused on the improving the students' skill in reading comprehension at the fourth semester students of English Department FKIP UM Mataram. The research was conducted in two cycles activity through planning, action, observing and reflecting procedure.

The first step was preliminary study, the researcher designed the procedure of ThinkPair-Share (TPS) technique, arranged the lesson plan, preparing materials and media, assessment and rubric resources and set up the criteria of success. The second step was implementation. The researcher applied the planning of treating the students with Think-Pair-Share (TPS) technique in teaching and learning process.

The next step after implementation was observation, the researcher observe the teaching and learning process and the process of collecting data. The observation of teaching and learning process is the interaction between teacher and students, among students and activities of the teacher in the class. The teacher will conduct test and interview to collect the data. Test was given to know the students' reading score. Interview was conducted to know the students response whether Think-Pair-Share (TPS) technique improves their reading skill.

\section{RESULT}

\section{The Finding at Cycle 1}

The cycle 1 had been conducted on July 5th and 12th 2018 within 2 meetings. The study was started with the Acting/implementing the action. In this stage the researcher implemented the Think Pair Share technique in teaching reading. The second meeting was used to observe the students' reading ability by giving them a reading test and the students had to answer the test through the TPS technique as well. The researcher gave text to the students to be read and to be understood,. Later on they were assigned to work in pairs to discuss some important information both explicit and implicit information in the text given. After that, each pair had to share the result of their pair's discussion to the class. At last, the researcher asked them to answer the test individually due to the information they got.

After the test was conducted, the researcher made a reflection with regard to the result of the students' test. Based on the test, it was found that $47 \%$ of students met the criteria of success score namely $\geq 75$ with the detail as follows: $2(6.7 \%)$ students got 85 , $5(16.7 \%)$ students got 80 , and $7(23.3 \%)$ got 75 . Meanwhile the rest of them or $53 \%$ students still failed that consisted of $3(10 \%)$ students got $70,4(13.3 \%)$ students got 65 , $2(6.7 \%)$ students got 60 and $7(23.3 \%)$ of students' scores are under 60 , it means that the criteria of success was not met in the cycle 1. For more detail, see the table below:

Table 1. The Students' Score at Cycle 1

\begin{tabular}{|c|c|c|c|c|c|c|}
\hline No & Students & $\begin{array}{c}\text { Number } \\
\text { of Test } \\
\text { Items }\end{array}$ & $\begin{array}{c}\text { Number of } \\
\text { Correct } \\
\text { Answers }\end{array}$ & $\begin{array}{c}\text { Number of } \\
\text { Incorrect } \\
\text { Answers }\end{array}$ & Score & Remarks \\
\hline 1 & AS & \multirow{5}{*}{20} & 16 & 4 & 80 & Pass \\
\hline 2 & $\mathrm{Ak}$ & & 10 & 10 & 50 & Fail \\
\hline 3 & ABS & & 8 & 12 & 40 & Fail \\
\hline 4 & ANQ & & 12 & 8 & 60 & Fail \\
\hline 5 & BRAA & & 15 & 5 & 75 & Pass \\
\hline
\end{tabular}




\begin{tabular}{|c|c|c|c|c|c|}
\hline 6 & DS & 14 & 6 & 70 & Fail \\
\hline 7 & DTB & 16 & 4 & 80 & Pass \\
\hline 8 & EM & 15 & 5 & 75 & Pass \\
\hline 9 & GMF & 16 & 4 & 80 & Pass \\
\hline 10 & $\mathrm{H}$ & 12 & 8 & 60 & Fail \\
\hline 11 & HRAP & 8 & 12 & 40 & Fail \\
\hline 12 & HA & 15 & 5 & 75 & Pass \\
\hline 13 & JAS & 13 & 7 & 65 & Fail \\
\hline 14 & LMAY & 15 & 5 & 75 & Pass \\
\hline 15 & LL & 17 & 3 & 85 & Pass \\
\hline 16 & LDK & 13 & 7 & 65 & Fail \\
\hline 17 & $\mathrm{MF}$ & 10 & 10 & 50 & Fail \\
\hline 18 & MSA & 15 & 5 & 75 & Pass \\
\hline 19 & $\mathrm{MZ}$ & 9 & 11 & 45 & Fail \\
\hline 20 & NA & 13 & 7 & 65 & Fail \\
\hline 21 & NAH & 15 & 5 & 75 & Pass \\
\hline 22 & $\mathrm{NH}$ & 14 & 6 & 70 & Fail \\
\hline 23 & NR & 10 & 10 & 50 & Fail \\
\hline 24 & PAN & 16 & 4 & 80 & Pass \\
\hline 25 & RNHT & 13 & 7 & 65 & Fail \\
\hline 26 & SR & 15 & 5 & 75 & Pass \\
\hline 27 & SyA & 17 & 3 & 85 & Pass \\
\hline 28 & TW & 14 & 6 & 70 & Fail \\
\hline 29 & YA & 8 & 12 & 40 & Fail \\
\hline 30 & ZQ & 16 & 4 & 80 & Pass \\
\hline \multicolumn{4}{|c|}{ Mean Score } & 67 & \\
\hline
\end{tabular}

Of the table above, we can see that only 14 (fourteen) students or $47 \%$ students who met the criteria of success in accordance to the reading test in the cycle 1 . Since the total number of tests/questions are 20 (twenty), then the score of students are gained through the multiplication of the students' correct answer by 5 (five). Furthermore, the mean score of the test was 63.5 , it was higher than the mean score at the preliminary study. There was a progress actually, but this cycle must be continued to the next cycle because only $47 \%$ or less than $60 \%$ students who met the criteria of success. Apart from the test, the students seemed more interested in learning reading using the TPS technique. It was indicated by their enthusiasm in sharing their ideas and in asking what they have never known in the text given.

\section{Revision of Cycle 1}

Prior to going to the next cycle, the researcher and his collaborator conducted some revision to the steps of Think-Pair-Share strategy. First, in the whilst-activity, before arriving at thinking process, students were assigned to pinpoint some difficult words at the text, and they were requested to find the meaning of those words in the dictionary and then adjusting them with the context. This step was done to facilitate the students in comprehending the text more easily. Second, in the first cycle the pairs were determined by the students themselves, most of the higher level students paired with the higher ones, and the lower ones were in pairs with the lower ability students too. As a result, the higher levels one got good score in the test, and the lower ones got poor 
score. In the cycle 2, the researcher mixed the higher level students with the lower ones. It was expected that the higher level students would be able to assist their mates in comprehending the content of text.

\section{The Finding at Cycle 2}

The cycle 2 was also conducted in two meetings on July 19th and 26th 2018, the first meeting for implementing the action and the second meeting for observing the students' ability. In the implementing stage, the researcher applied the TPS strategy based on the revision made with the collaborator. Later on the test was given to the students to measure their ability. The result showed that there was a significant progress on the students' score. 1 (one) out of 30 students or (3.3\%) got 95, 3 (10\%) students got 90, 2 (two) students (7\%) got 85, 8 (eight) of them (26.7\%) got 80, 6 (six) students (20\%) got $75,4(13 \%)$ students got $70,2(7 \%)$ students got $65,2(7 \%)$ got 60 , and the last 2 students or $7 \%$ were absent at the day of test taken. See the following table for more details.

Table 2. The Students' Score at Cycle 2

\begin{tabular}{|c|c|c|c|c|c|c|}
\hline No & Students & $\begin{array}{c}\text { Number } \\
\text { of Test }\end{array}$ & $\begin{array}{c}\text { Number of } \\
\text { Correct } \\
\text { Answers } \\
\end{array}$ & $\begin{array}{c}\text { Number of } \\
\text { Incorrect } \\
\text { Answers }\end{array}$ & Score & Remarks \\
\hline 1 & AS & \multirow{26}{*}{20} & 17 & 3 & 85 & Pass \\
\hline 2 & $\mathrm{Ak}$ & & 13 & 7 & 65 & Fail \\
\hline 3 & ABS & & 14 & 6 & 70 & Fail \\
\hline 4 & ANQ & & 14 & 6 & 70 & Fail \\
\hline 5 & BRAA & & 16 & 4 & 80 & Pass \\
\hline 6 & DS & & 15 & 5 & 75 & Pass \\
\hline 7 & DTB & & 18 & 2 & 90 & Pass \\
\hline 8 & EM & & 16 & 4 & 80 & Pass \\
\hline 9 & GMF & & 17 & 3 & 85 & Pass \\
\hline 10 & $\mathrm{H}$ & & 14 & 6 & 70 & Fail \\
\hline 11 & HRAP & & 0 & 0 & 0 & Fail \\
\hline 12 & HA & & 16 & 4 & 80 & Pass \\
\hline 13 & JAS & & 15 & 5 & 75 & Pass \\
\hline 14 & LMAY & & 16 & 4 & 80 & Pass \\
\hline 15 & LL & & 18 & 2 & 90 & Pass \\
\hline 16 & LDK & & 15 & 5 & 75 & Pass \\
\hline 17 & $\mathrm{MF}$ & & 0 & 0 & 0 & Fail \\
\hline 18 & MSA & & 16 & 4 & 80 & Pass \\
\hline 19 & $\mathrm{MZ}$ & & 13 & 7 & 65 & Fail \\
\hline 20 & NA & & 15 & 5 & 75 & Pass \\
\hline 21 & $\mathrm{NAH}$ & & 16 & 4 & 80 & Pass \\
\hline 22 & $\mathrm{NH}$ & & 15 & 5 & 75 & Pass \\
\hline 23 & NR & & 12 & 8 & 60 & Fail \\
\hline 24 & PAN & & 16 & 4 & 80 & Pass \\
\hline 25 & RNHT & & 14 & 6 & 70 & Fail \\
\hline 26 & SR & & 16 & 4 & 80 & Pass \\
\hline
\end{tabular}




\begin{tabular}{|c|c|c|c|c|c|}
\hline 27 & SyA & 19 & 1 & 95 & Pass \\
\hline 28 & TW & 15 & 5 & 75 & Pass \\
\hline 29 & YA & 12 & 8 & 60 & Fail \\
\hline 30 & $\mathrm{ZQ}$ & 18 & 2 & 90 & Pass \\
\hline \multicolumn{4}{|c|}{ Mean Score } & 71.83 & \\
\hline
\end{tabular}

Based on the result of reading test above, the researcher and his collaborator decided that the CAR could be completed since 20 out 30 students or $67 \%$ students has met the criteria of success namely $\geq 75$. This result is higher than the expectation of the researcher in which the criteria of success determined by the researcher revealed that if $60 \%$ students get $\geq 75$, then the cycle can be completed.

Furthermore, based on the result of interview regarding the students' opinion about the TPS Technique, most of the students responded that the TPS technique is really helpful in solving their problem in figuring out the text comprehensively. Besides, the TPS technique can encourage and motivate them to read and to comprehend the text.

\section{Overall Findings}

The results of tests in the preliminary study, cycle 1 , and cycle 2 shows that students' reading comprehension has regularly improved. It means that the TPS technique improved the students' ability in answering the test of the reading text. In other words, the use of TPS technique could increasingly help and motivate them to learn for better text understanding. Thus, most of them gradually gained good scores at the end of each cycle, most significantly in Cycle 2. Look at the chart below to see the progress of each cycle.

Chart 1. Number and Percentage of Students who met the criteria of success along with the mean score at the Preliminary Study, Cycle 1, and Cycle 2

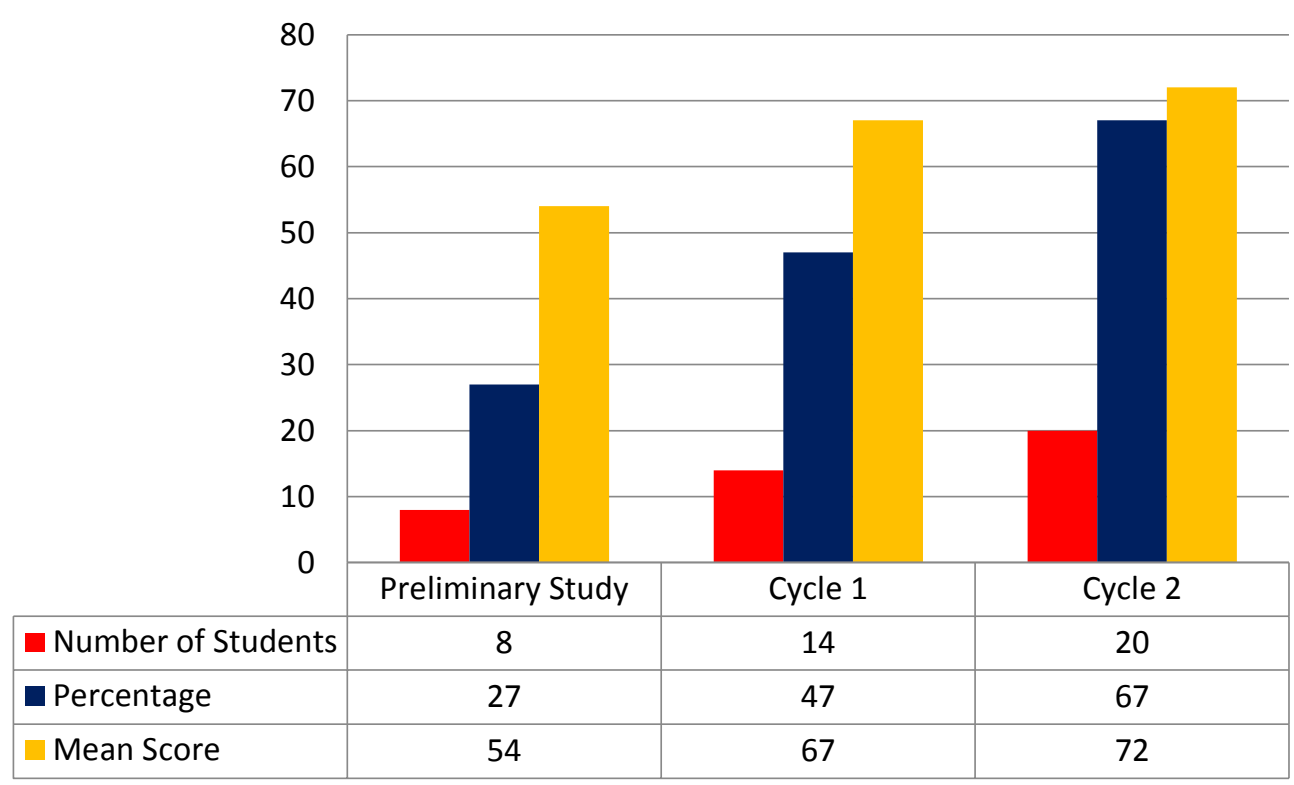

In the reading comprehension test, 8 (27\%) out of 30 (thirty) students got $\geq 75$ and the mean score was 54 in the preliminary study, 14 (fourteen) students (47\%) got $\geq 75$ in the cycle 1 with the mean score 67, and in the cycle 2, 20 (twenty) students (67\%) got $\geq 75$ with the mean score 72 .

\section{Discussion}

Think-Pair-Share is a cooperative learning strategy that is able to assist the students to solve the problem in grasping the text. It gives the students more time to think, to 
respond, and to help each other (Arends, 1997). Besides, it encourages individual participation and is applicable across all grade levels and class sizes in addition to being helpful in organizing students' knowledge and motivating in learning new topics. As one of the cooperative learning strategies, Think-Pair-Share strategy encourages students to work collaboratively faster and more efficiently, have greater retention, and feel more positive about the learning experience (Newhorizon.org, 2005).

The result of the research using Think-Pair-Share strategy indicated that there was an increase in students' average scores, from 54 in the preliminary study, 67 in the Cycle 1 and 72 in the Cycle 2. Besides, the number of students who got 75 or more was also increased, from eight students $(27 \%)$ in the preliminary study, fourteen $(47 \%)$ students in the cycle 1 , to twenty students $(67 \%)$ in the cycle 2 . The result was in line with the result of the study conducted by Patiiha (2006). She studied on improving the learning of beginning reading by using the Think-Pair-Share strategy. The findings revealed that Think-Pair-Share strategy could be applied to improve the implementation of beginning reading at the planning, implementation, or evaluation stage.

Besides, the result of the study using TPS strategy showed that the students' active participation was increased. The number of students shared, asked and answered questions was increased. This occurred since the technique encouraged students to share ideas, asking questions as well as answering questions between pairs. Thus, simultaneous interactions between pairs and among class were apparent.

The success of the implementation of Think-Pair-Share strategy that had been proven to improve the students' reading comprehension as well as enhancing students' participation in terms of sharing ideas, asking and answering the questions was closely related to the role of the lecturer. Thelecturer/ teacher did not only involve in designing lesson plan, preparing the materials as well as the media but also in developing the procedures of Think-Pair-Share strategy that ultimately resulted in the increase of students' reading comprehension scores and participation. Thus, thelecturer's role was definitely crucial for the successful implementation of the strategy. It was proven when the lecturer developed the Think-Pair-Share strategy. Although the main core of ThinkPair-Share strategy was in the whilst-reading activities, the lecturer did not only revise the strategy in whilst-reading activities, but also in pre-reading activities and postreading activities, because the whole procedures of Think-Pair-Share strategy are conducted into three phases; pre-reading activities, whilst-reading activities and postreading activities.

\section{CONCLUTION}

After the Think-Pair-Share was implemented through the cycle 1 and the cycle 2, the researcher concluded that the TPS technique is able to improve the reading ability of the fourth semester students of English Language Department, Faculty of Teacher Training and Education, Muhammadiyah University of Mataram. It was indicated by the improvement of the students' score in reading test starting from the preliminary study, the cycle 1 , and the cycle 2 . In the preliminary study, only eight students or $27 \%$ who met the criteria of success namely got the score 75 or more and the average score was 54. Later on, in the cycle 1 there was an improvement, fourteen out of thirty students or $47 \%$ reached the criteria of success with the average score 67 . At last, in the cycle 2 , $67 \%$ students or 20 (twenty) out of 30 (thirty) students met the criteria of success and the average score was 72 .

Besides gaining improvement in the reading score, the students also seemed enthusiastic in thinking, pairing and sharing their ideas. They stated that this technique 
is able to encourage and motivate them in thinking, exploring and sharing their opinion and ideas. This technique is also good to enhance the cooperation with other people. Finally, TPS technique is also able to increase the students' confidence to share their ideas in front of many people..

\section{REFERENCE}

[1] Abdurrahman. E, Susilawati, E, and Arifin, Z. (2012). Improving students' ability in Reading Comprehension through Cooperative learning (Think-Pair-Share). Pontianak. Tanjung Pura University.

[2] Anderson. (2003). Reading. In David Nunan (2003) Practical English Language Teaching (1 $1^{\text {st }}$ Edition) New York: McGraw Hill.

[3] Arends, R. I. 1997. Introduction to Classroom Instruction and Management.

[4] New York: McGraw-Hill Company, Inc.

[5] Awad Raba, A.A. (2017). The Influence of Think-Pair-Share on Improving Students' Oral Communication Skills in EFL Classrooms. Creative Education, Volume 8. 12-23.

[6] Bamiro, Adekunle 0. (2015). Effect of guided discovery and Think-Pair-Share Strategies on Secondary school students' achievement in Cemistry. SAGE Open. January-March 1-7.

[7] Harmer. J. (2007). How to teach writing. England: Pearson education limited.

[8] Grabe, S. and Staller F. L. (2002). Teaching and Researching Reading. England: Longman.

[9] Jannah, Nikmatul. (2013). The effectiveness of Think-Pair-Share Technique in Teaching Reading. Jurnal Penelitian, Pendidikan dan Pengajaran FKIP UNISMA Vol.1 No 12.

[10] Kagan, S \& Kagan, M. (2009). Kagan Cooperative Learning. California: Kagan Publishing.

[11] Kemmis, S. and R. McTaggart (eds). (1988). Action Research Planner $3^{\text {rd }}$ Edition. Melbourne: Deakin University Press.

[12] Narulaya, D.R. Nadrun, Budi. (2014). Increasing Reading Comprehension of the Eleventh grade students through Think-Pair-Share (TPS) technique. E-journal of English Language Teaching Society (ELTS) Vol.2 No.1 ISSN 2331-1841.

[13] Nejad, S.G. \& Keshavarzi, A. (2015). The effect of Cooperative Learning on Reading Comprehension and Reading Anxiety of Pre-University Students. Journal of Applied Linguistics and Language Research, Volume 2, Issue 8, pp.169-180 ISSN: 2376-760X.

[14] Nuttal, C. (1996). Teaching Reading Skills in a Foreign Language. Cambridge: Cambridge University Press.

[15] Pattiiha, H.2006. An Application of the Think-Pair-Share to Improve the Implementation of the Learning of Beginning Reading Among Second Year Students at SDN Sumbersari II Malang. Unpublished Thesis of State University of Malang.

[16] Rahvard, Z.J. (2010). Cooperative Learning Strategies and Reading Comprehension. California Linguistic Notes. XXXV (2), 1-15.

[17] Sampsel, Ariana. (2013). Finding the Effect of Think-Pair-Share on Student confidence and participation. Honors Project. Paper 28.

[18] Shih, Y.C. \& Reynold, B.L. (2015). Teaching Adolescents EFL by Integrating ThinkPair-Share and reading Strategy Instruction: A Quasy- Experimental Study. RELC Journal 1-15.

[19] Slavin, R.E. (2011). Cooperative Learning. Teori, Riset, dan Praktik. Bandung: Nusa Media. 
[20] Sugiarto, D. \& Sumarsono, P. (2014). The Implementation of Think-Pair-Share Model to Improve students' ability in reading Narrative Text. International Journal of English and Education Volume:3 Issues:3

[21] Sukyadi, D \& Hasanah, E.U. (2010). Scaffolding Students' Reading Comprehension with Think-Aloud Strategy. Indonesia: The Language Center, Indonesia University Education.

[22] Supriyono, Agus. (2013). Cooperative Learning. Teori dan Aplikasi Paikem. Yogyakarta. Pustaka Pelajar.

[23] Tompkins, G.E., \& Hoskinson. K. (1991). Language Art: Content and Teaching Strategies. New York: Macmillan Publishing Company.

[24] Wallace, C. (1992). Reading. Cambridge: Oxford University Press.

[25] Weaver, C. (1994). Reading Process and Practice. Portsmouth: Heinermann.

[26] Wichadee, S. (2005). The Effects of Cooperative Learning on English Reading Skill and Attitudes of the First- Year Students at Bangkok University. BU academic Review, 4 (2), 22-31. 